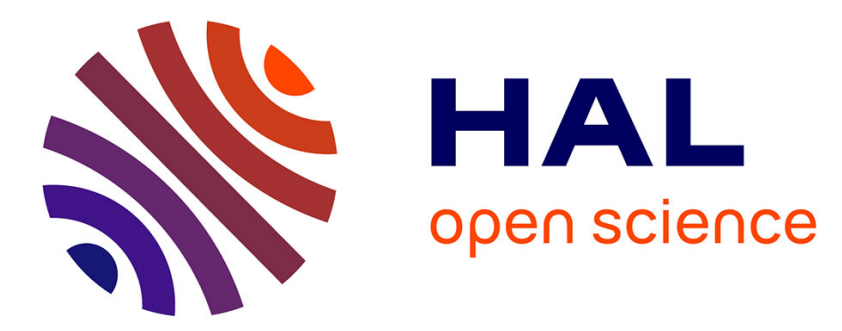

\title{
Coupling experimental and field-based approaches to decipher carbon sources in the shell of the great scallop, Pecten maximus (L.)
}

V Marchais, J Richard, A Jolivet, Jonathan Flye-Sainte-Marie, Julien Thébault, Fred Jean, P Richard, Yves-Marie Paulet, Jacques Clavier, Laurent Chauvaud

\section{To cite this version:}

V Marchais, J Richard, A Jolivet, Jonathan Flye-Sainte-Marie, Julien Thébault, et al.. Coupling experimental and field-based approaches to decipher carbon sources in the shell of the great scallop, Pecten maximus (L.). Geochimica et Cosmochimica Acta, 2015, 168, pp.58-69. 10.1016/j.gca.2015.07.010 . hal-01211666

\section{HAL Id: hal-01211666 https://hal.science/hal-01211666}

Submitted on 5 Oct 2015

HAL is a multi-disciplinary open access archive for the deposit and dissemination of scientific research documents, whether they are published or not. The documents may come from teaching and research institutions in France or abroad, or from public or private research centers.
L'archive ouverte pluridisciplinaire HAL, est destinée au dépôt et à la diffusion de documents scientifiques de niveau recherche, publiés ou non, émanant des établissements d'enseignement et de recherche français ou étrangers, des laboratoires publics ou privés. 


\section{Accepted Manuscript}

Coupling experimental and field-based approaches to decipher carbon sources in the shell of the great scallop, Pecten maximus (L.)

V. Marchais, J. Richard, A. Jolivet, J. Flye-Sainte-Marie, J. Thébault, F. Jean, P. Richard, Y.-M. Paulet, J. Clavier, L. Chauvaud

PII:

S0016-7037(15)00443-3

DOI: http://dx.doi.org/10.1016/j.gca.2015.07.010

Reference: GCA 9364

To appear in:

Geochimica et Cosmochimica Acta

Received Date:

24 July 2014

Accepted Date:

8 July 2015

Please cite this article as: Marchais, V., Richard, J., Jolivet, A., Flye-Sainte-Marie, J., Thébault, J., Jean, F., Richard, P., Paulet, Y.-M., Clavier, J., Chauvaud, L., Coupling experimental and field-based approaches to decipher carbon sources in the shell of the great scallop, Pecten maximus (L.), Geochimica et Cosmochimica Acta (2015), doi: http:// dx.doi.org/10.1016/j.gca.2015.07.010

This is a PDF file of an unedited manuscript that has been accepted for publication. As a service to our customers we are providing this early version of the manuscript. The manuscript will undergo copyediting, typesetting, and review of the resulting proof before it is published in its final form. Please note that during the production process errors may be discovered which could affect the content, and all legal disclaimers that apply to the journal pertain. 


\section{Coupling experimental and field-based approaches to decipher carbon sources in the shell of the great scallop, Pecten maximus $\left(\mathrm{L}_{\circ}\right)$}

Marchais V. ${ }^{\text {a, }}$, Richard J. ${ }^{\text {a, * }}$, Jolivet A. a , Flye-Sainte-Marie J. a, Thébault J. a, Jean F. a, Richard P.

b, Paulet Y.-M. ${ }^{\text {a }}$, Clavier J. ${ }^{\text {a }}$, Chauvaud L. ${ }^{\text {a }}$

${ }^{a}$ UMR 6539, LEMAR, Université de Bretagne Occidentale, Institut Universitaire Européen de la Mer, Technopôle Brest-Iroise, rue Dumont d’Urville, 29280 Plouzané, France

${ }^{\mathrm{b}}$ UMR 7266, LIENSs, Université de la Rochelle, 2 rue Olympe de Gouges, 17000 La Rochelle, France

* Both authors equally contributed to this manuscript

Corresponding author:

Violette Marchais

Email: vmarchais@gmail.com

\section{Abstract}

This research investigated how the carbon isotopic composition of food source $\left(\delta^{13} \mathrm{C}_{\text {food }}\right)$ and dissolved inorganic carbon $\left(\delta^{13} \mathrm{C}_{\mathrm{DIC}}\right)$ influences the carbon isotopic composition of Pecten maximus shells $\left(\delta^{13} \mathrm{C}_{\text {shell }}\right)$ under both experimental and natural conditions. The objectives are to better understand the relationship between $P$. maximus and its environment, and to specifically distinguish conditions under which calcification is influenced by respired $\mathrm{CO}_{2}$ derived from food sources versus conditions in which calcification uses inorganic carbon from seawater. Laboratory experiment investigated carbon incorporation into shell carbonates by maintaining scallops under conditions where the stable carbon isotopic composition of food sources was considerably depleted (-54\%o), relative to values observed in the natural environment $(-21 \%$ ). Laboratory experiment ran for 78 days under three temperature conditions, $15^{\circ} \mathrm{C}, 21^{\circ} \mathrm{C}$ and $25^{\circ} \mathrm{C}$. A survey of the environmental parameters and stable carbon isotopic composition into shell carbonate of natural population of $P$. maximus was also realized during the same year in the Bay of Brest, France. Data collected from both laboratory experiment and the natural environment confirmed that both $\delta^{13} \mathrm{C}_{\mathrm{DIC}}$ and $\delta^{13} \mathrm{C}_{\text {food }}$ influence $\delta^{13} \mathrm{C}_{\text {shell }}$ values and that organic carbon incorporation $\left(\mathrm{C}_{\mathrm{M}}\right)$ averages about $10 \%$ ( 4.3 to $6.8 \%$ under experimental conditions and 1.9 to $16.6 \%$ in the natural environment). The shift in stable carbon isotopic composition from the uptake of depleted food sources under experimental conditions realized a marked divergence in the predicted equilibrium between calcium carbonate and 
ambient bicarbonate, relative to the natural environment. This offset was $1.7 \pm 0.6 \%$ for scallops in their natural environment and $2.5 \pm 0.5$ and $3.2 \pm 0.9 \%$ for scallops under experimental conditions at water temperatures of 15 and $21^{\circ} \mathrm{C}$, respectively. The offset of $3 \%$ for scallops subjected to laboratory experiment could not be explained in light of growth rate but may be related to food supply and/or temperature. Food source and temperature effects may also explain the annual variation observed in $C_{M}$ values measured from scallops in their natural environment. $C_{M}$ estimation from the natural population of $P$. maximus varied seasonally from around $2 \%$ at the end of winter, to $12 \%$ in summer. The seasonal variation resembles variability in the carbon isotopic composition of the food sources throughout the year with an exception at the end of winter.

Keywords: stable carbon isotopes, metabolic carbon, DIC, respired carbon, Pecten maximus, experiment 


\section{Introduction}

Mollusk shell is a composite biomineral comprised of 95 to 99 weight \% calcium carbonate. Shell cross sections exhibit two or three super-imposed calcium carbonate layers, made of either aragonite or calcite (Marin and Luquet, 2004). Mollusks precipitate carbonate from ambient seawater such that the structure composition, carbon and oxygen stable isotopic ratios, and other features of successive shell bands record environmental conditions (Davenport, 1938; Stanton and Dodd, 1970; Krantz et al., 1987; Schöne et al., 2003). Based on evidence of the influence of water temperatures and isotopic composition $\left(\delta^{18} \mathrm{O}_{\mathrm{w}}\right.$ related to salinity) on oxygen isotopic composition of biogenic carbonate $\left(\delta^{18} \mathrm{O}_{\text {shell }}\right)$ (Urey, 1947; Epstein et al., 1953; Craig, 1965; Emiliani, 1966; Shackleton, 1967; O'Neil et al., 1969), $\delta^{18} \mathrm{O}_{\text {shell }}$ values have been used to estimate past temperature and salinity parameters (Grossman and Ku, 1986; Ingram et al., 1996; Chauvaud et al., 2005; Schöne et al., 2005; Wanamaker et al., 2007). Carbon isotopic ratios of the shell $\left(\delta^{13} \mathrm{C}_{\text {shell }}\right)$ are derived from the stable carbon isotope ratio of dissolved inorganic carbon $\left(\delta^{13} C_{\text {DIC }}\right)$ in seawater (Mook and Vogel, 1968; Mook, 1971; Killingley and Berger, 1979; Arthur et al., 1983), metabolic carbon (Klein et al., 1996; Geist et al., 2005; McConnaughey and Gillikin, 2008) or some combination of the two (Tanaka et al., 1986; McConnaughey et al., 1997; Dettman et al., 1999; Furla et al., 2000; Vander Putten et al., 2000; Lorrain et al., 2004; Gillikin et al., 2006; Chauvaud et al., 2011). Physiological parameters (e.g., growth rates, metabolism, ontogeny, food source variations) can complicate $\delta^{13} \mathrm{C}_{\text {shell }}$ data interpretation due to their influence on biomineralization (Shackleton et al., 1973; Erez, 1978; Swart, 1983; Gonzalez and Lohmann, 1985; McConnaughey, 1989a, b; Owen et al., 2002a, b).

Values for marine mollusk $\delta^{13} \mathrm{C}_{\text {shell }}$ are primarily controlled by three factors: $\delta^{13} \mathrm{C}_{\mathrm{DIC}}, \delta^{13} \mathrm{C}$ of respired carbon $\left(\delta^{13} C_{R}\right)$ and proportion of metabolic carbon $\left(C_{M}\right)$ incorporated into shell material (McConnaughey, 1989a; McConnaughey et al., 1997; McConnaughey and Gillikin, 2008; Beirne et al., 2012). McConnaughey et al. (1997) calculated a theoretical metabolic carbon contribution of $10 \%$ for aquatic mollusks based on the "respiratory gas exchange model". However, recent experimental and empirical studies have documented several deviations from this model indicating that $C_{M}$ appears to be species-specific (e.g., Lorrain et al., 2004; Gillikin et al., 2006; Gillikin et al., 2007), even in the marine environment, and that $C_{M}$ shows species-specific variation over the lifetime of an individual (Klein et al., 1996; Lorrain et al., 2004; Gillikin et al., 2009; Butler et al., 2011; Chauvaud et al., 2011).

Poulain et al. (2010) and Beirne et al. (2012) used the Manila clam (Venerupis philippinarum) and ocean quahog (Arctica islandica), respectively, to provide rigorous, species-specific 
experimental calibration of $\delta^{13} \mathrm{C}_{\text {shell }}$ with $\delta^{13} \mathrm{C}_{\text {DIC }}$ for mollusk shell carbonate. Both research teams found a metabolic carbon contribution of $\sim 10 \%\left(\mathrm{C}_{\mathrm{M}}=12 \%\right.$ for Manila clam and $10 \%$ for ocean quahog) and concluded that ambient DIC exerts primary control on $\delta^{13} \mathrm{C}_{\text {shell. }}$. The investigation by Chauvaud et al. (2011) examining ontogenetic and seasonal variations in Pecten maximus shells, found that $\delta^{13} \mathrm{C}_{\text {shell }}$ values did not reliably track $\delta^{13} \mathrm{C}_{\mathrm{DIC}}$ variation, but might represent a promising tool for ecophysiological studies.

The present study focuses on the carbon isotopic composition of the Pecten maximus shell. This species is a ubiquitous marine mollusk that range from Spain to Norway and resides in water depths of 0 to $500 \mathrm{~m}$. The biology of the scallop is well understood in terms of growth rate, reproduction and energy allocation (Paulet et al., 1988; Chauvaud et al., 1998; Saout et al., 1999; Lorrain et al., 2002). P. maximus has a high growth rate (up to $400 \mu \mathrm{m}$.day ${ }^{-1}$ along the shell's dorso-ventral axis) and produces daily growth bands from spring to fall (Chauvaud et al., 1998; Chauvaud et al., 2005). This daily pattern of striae allows the carbonate deposits along the shell's growth axis to be precisely dated (Chauvaud et al., 1998; Chauvaud et al., 2005; Chauvaud et al., 2012). It also enables precise calibration of geochemical tracers during the growth period (see Schöne et al., 2002), to a degree not typically possible with other species (e.g. Wanamaker et al., 2007; Beirne et al., 2012).

As outlined by McConnaughey and Gillikin (2008), the use of $\delta^{13} \mathrm{C}_{\text {shell }}$ as an environmental proxy requires a better understanding of processes influencing calcification and whether it dominated by respired $\mathrm{CO}_{2}$ derived from food or inorganic carbon from ambient seawater. We addressed these questions by measuring the carbon isotopic composition of shell carbonate from controlled laboratory experiment, in which scallops were fed phytoplankton with a depleted carbon isotopic composition $\left(\delta^{13} \mathrm{C}_{\text {algae }}\right.$ depleted in ${ }^{13} \mathrm{C}$ relative to values in natural environment $)$. Three temperature conditions were applied corresponding to temperatures recorded in the field: (1) at the beginning of the experiment $\left(15^{\circ} \mathrm{C}\right),(2)$ maximum temperature encountered throughout the natural range for $P$. maximus $\left(21^{\circ} \mathrm{C}\right)$ and $(3)$ an extreme physiologically stressfully temperature $\left(25^{\circ} \mathrm{C}\right)$. The experiment lasted 78 days, allowing enough time for $\delta^{13} \mathrm{C}_{\text {algae }}, \delta^{13} \mathrm{C}_{\mathrm{DIC}}, \delta^{13} \mathrm{C}_{\text {tissues }}$ and $\delta^{13} \mathrm{C}_{\text {shell }}$ to reach a new steady-state. The main goals of the experimental trial were to control factors, such as temperature and food source, that covary in the natural environment, and to determine their influence on carbon incorporation into shell carbonate. To better understand $P$. maximus' carbon dynamics, experimental conditions varied the stable carbon isotope composition of the organism's food sources over a wide range (ranging from $-21 \%$ under natural conditions to $-54 \%$ under experimental conditions) and maintained stable temperatures under three temperature conditions. Under experimental conditions, the stable carbon isotopic composition was measured from shell carbonate. A survey of the 
environmental parameters and stable carbon isotopic composition into shell carbonate of $P$. maximus was also realized during the same year at the Lanvéoc locality, Bay of Brest, France (Fig. 1). Scallop $\delta^{13} \mathrm{C}_{\text {shell }}$ was specifically monitored in detail over one year of growth to establish estimates of seasonal variation in metabolic carbon incorporation. These results were then analyzed in light of the experimental results.

\section{Material and methods}

\subsection{Biological material}

Pecten maximus used for the experimental study came from a single cohort spawned at the Tinduff bivalve hatchery (Bay of Brest, France, Fig. 1) in spring 2010. The juveniles were then raised in small cages at Sainte-Anne du Portzic (Bay of Brest, Fig. 1) from June 2010 to the end of May, 2011. On May 31 ${ }^{\text {st }}$, 2011, 1320 P. maximus individuals (1 year old; average length $=34.0 \pm 4.1$ $\mathrm{mm}, 1 \sigma)$ were transferred to Argenton Shellfish Laboratory of the French Research Institute for Exploitation of the Sea (IFREMER, Brittany, France, Fig. 1) where experiment was conducted. By convention, the age class is the number of first Januaries experienced by an individual, easily controlled by the number of winter marks on the shell's outer surface. The scallops evaluated in this study were class I.

\subsection{Experimental conditions}

Scallops were divided randomly into three batches of 440 individuals each, and placed in plastic mesh cages inside three $250 \mathrm{~L}$ tanks subjected to different temperature conditions: $15^{\circ} \mathrm{C}(\mathrm{T} 15), 21^{\circ} \mathrm{C}$ (T21) and $25^{\circ} \mathrm{C}$ (T25). Water within the tanks was homogenized with aquarium pumps. Each tank was supplied with $80 \mathrm{~L} . \mathrm{h}^{-1}$ of seawater filtered at $1 \mu \mathrm{m}$. Tanks were completely emptied and cleaned once a week.

Throughout the experiment, water flowing into the tanks was continuously supplemented with a 50/50 (volume) mixture of two cultured microalgae (50\% Isochrysis affinis galbana -Tahitian strain T-iso - and $50 \%$ Chaetoceros gracilis) depleted in ${ }^{13} \mathrm{C}$. These microalgae with low carbon isotope ratios $\left(\delta^{13} \mathrm{C}_{\text {algae }}\right)$ were produced by bubbling $\mathrm{CO}_{2}$ from a commercial cylinder of petrochemical origin 
into culture medium (see Paulet et al., 2006 for more details). The quantity of microalgae added to each tank was adjusted twice a day to maintain a concentration of $3 \times 10^{4}$ cells. $\mathrm{mL}^{-1}$ within the tanks $\left(1.5 \times 10^{6} \mu \mathrm{m}^{3} \cdot \mathrm{mL}^{-1}\right)$, so that food was never a limiting factor, independently of temperature and number of individuals in tanks (Utting and Millican, 1998; Fig. 2A). Algal concentrations were checked twice a day using a Coulter counter. The experiment lasted for 78 days (ending on August $\left.16^{\text {th }}, 2011\right)$, and maintained a photoperiod $(12 \mathrm{~h} / 12 \mathrm{~h})$, salinity, $\mathrm{pH}$ and $\mathrm{O}_{2}$ concentration at constant levels. Salinity, $\mathrm{pH}$ and $\mathrm{O}_{2}$ concentration were measured once a week using WTW probes (WTW Multi 3430 Multiparameter Meter equipped with TetraCon 925 salinity probe, SenTix pH probe and FDO 925 oxygen optode). Their average values ( \pm S.D.) were $35.8 \pm 0.2$ (PSU), $8.1 \pm 0.1$ and $94 \pm$ $7 \%$, respectively.

During the initial 21 days, all scallops were maintained at $15.1 \pm 0.2^{\circ} \mathrm{C}$, a temperature approximating that of the natural environment. This allowed acclimation to controlled conditions as well as identification and removal of damaged individuals prior to experimentation. On June $22^{\text {nd }}$, 2011, temperature was increased at a rate of $1^{\circ} \mathrm{C}$.day ${ }^{-1}$ to $21^{\circ} \mathrm{C}$ in T21 (stable by June $28^{\text {th }}$, 2011; Fig. $2 \mathrm{~A}$ ) and to $25^{\circ} \mathrm{C}$ in T25 (stable by July $7^{\text {th }}, 2011$; Fig. $2 \mathrm{~A}$ ). The $\mathrm{T} 15$ tank remained at $15^{\circ} \mathrm{C}$ (assumed at ambient temperature). Temperatures were recorded in each tank every 15 minutes using button data loggers (Signatrol SL52T Button Data Logger). Average temperature ( \pm S.D.) was $14.8 \pm 0.6^{\circ} \mathrm{C}$ (over 78 days) for the $\mathrm{T} 15$ tank, $21.4 \pm 0.2^{\circ} \mathrm{C}$ (over 50 days) for the $\mathrm{T} 21$ tank and $25.2 \pm 0.9^{\circ} \mathrm{C}$ (over 41 days) for the T25 tank (Fig. 2A).

\subsection{Sampling}

To monitor stable carbon isotopic composition of scallop tissues, five $P$. maximus were collected each week from each tank, beginning at the end of the acclimation period (June $21^{\text {st }}, 2011$ ) and continuing until the end of the experiment. Adductor muscle, digestive gland (stomach content expelled by rinsing with distilled water), mantle and gills were extracted from each individual, and frozen at $-20^{\circ} \mathrm{C}$.

At the end of the experiment, three scallops were collected from each tank and shells were analyzed for their stable carbon isotopic composition $\left(\delta^{13} \mathrm{C}_{\text {shell }}\right)$. In addition, three individuals of age class I from the natural population (referred to as "field" scallops) were sampled on October $24^{\text {th }}$, 2011 at Lanvéoc (Fig. 1), a sampling site where chlorophyll $a$ was recorded once a week from March 
to October (Chatterjee et al., 2013). The shells of these 12 scallops (nine from tanks and three from natural population) were used to determine growth rate and $\delta^{13} \mathrm{C}$ carbonate analysis.

To determine carbon isotope composition of food source $\left(\delta^{13} \mathrm{C}_{\text {algae }}\right), 5 \mathrm{~mL}$ of the microalgal mixture was sampled each week during the experiment. Samples were filtered with pre-combusted glass microfiber filters (Whatman GF/F). Prior to filtration, filters were rinsed with $10 \% \mathrm{HCl}$ followed by a rinse with distilled water. After filtration, filters were rinsed with distilled water, immediately dried $\left(12 \mathrm{~h}\right.$ at $\left.60^{\circ} \mathrm{C}\right)$ and stored in darkness until analysis according to Lorrain et al. (2003).

Water from each tank was sampled once a week for carbon isotope analysis of dissolved inorganic carbon $\left(\delta^{13} \mathrm{C}_{\mathrm{DIC}}\right)$. Surface seawater was also sampled at Lanvéoc once a week (from March to October 2011) using a Niskin bottle. Each water sample was fixed with $20 \mu \mathrm{L}$ of saturated mercuric chloride $\left(\mathrm{HgCl}_{2}\right)$ in a $12 \mathrm{~mL}$ glass vial (Gillikin and Bouillon, 2007).

2.4. Daily growth rate, preparation and calcium carbonate sampling of shell

The daily growth rate of the 12 sample shells (experimental + "field" scallops) was individually measured from the external surface of the left valve along the dorso-ventral growth axis (Chauvaud et al., 1998). The shells were first cleaned by sonication, rinsed in Milli-Q water and then air-dried. From the first visible stria near the umbo to the outer edge of the shell, the distance between two successive daily growth striae was measured from images acquired using a high-resolution digital camera (Sony DFW-X700) and analyzed using image analysis software (Visilog ${ }^{\circledR}$, Noesis).

The same 12 shells were also analyzed for carbon isotopic composition $\left(\delta^{13} \mathrm{C}_{\text {shell }}\right)$. The outer calcite layer of the flat valve was sampled using a Dremel drill with a $0.3 \mathrm{~mm}$ grinding tip. Small grooves were cut parallel to growth striae along the dorso-ventral axis, from the first winter growth mark to the ventral edge of the shell. Because daily growth rate is not constant, each carbonate sample included material from 1 to 5 striae. Sampling points were separated by spaces equivalent to 1 to 2 days of growth. A total of 522 aliquots of $P$. maximus calcite were collected, with an average of 30 samples from experimental shells and 80 samples from "field" shells. Aliquots exhibited average sample weights of $114 \pm 20 \mu \mathrm{g}$ and were stored in clean glass vials until analysis.

\subsection{Isotopic analysis}


Freeze-dried tissues were powdered and loaded into 8 x $5 \mathrm{~mm}$ tin cups (400 $\mu \mathrm{g}$ sample weight). Stable carbon isotopic analysis was performed at LIENSs - UMR7266 (University of La Rochelle, France) using an Elemental Analyzer (Flash EA 1112, Thermo Scientific) coupled to a Delta V Advantage isotope ratio mass spectrometer (IRMS) via a ConFlo IV interface. Isotopic data are expressed using conventional delta notation $(\delta)$ in \%o relative to the Vienna Pee Dee Belemnite (VPDB), according to Coplen (2011):

$$
\delta^{13} \mathrm{C}_{\text {sample }}=\left[\left(\mathrm{R}_{\text {sample }} / \mathrm{R}_{\text {standard }}\right)-1\right]
$$

where $\mathrm{R}={ }^{13} \mathrm{C} /{ }^{12} \mathrm{C}$. Error measurements were $<0.15 \%$ o $(1 \sigma)$ for $\delta^{13} \mathrm{C}$, as estimated using an internal acetanilide laboratory standard.

Filters with algal samples were decarbonated via exposure to $\mathrm{HCl}$ fumes in a dessicator for four hours (Lorrain et al., 2003), then loaded into 8 x $5 \mathrm{~mm}$ tin cups. Isotopic analysis followed the same methods used for tissue samples.

Stable carbon isotope ratios of total dissolved inorganic carbon $\left(\delta^{13} \mathrm{C}_{\mathrm{DIC}}\right)$ were measured at the Earth System Sciences Laboratory (Vrije Universiteit Brussel, Belgium) using an Elemental Analyzer (Flash 1112 EA Thermo Finnigan) coupled to a Thermo Delta V Plus IRMS via CONFLO III. Repeated analysis of standards (Gillikin and Bouillon, 2007) established measurement precision better than $0.2 \%$.

All carbonate isotopic analyses $\left(\delta^{13} \mathrm{C}_{\text {shell }}\right)$ were performed on a Finnigan MAT 252 IRMS equipped with a Kiel III automated sampling device at Stanford University, USA. Samples were acidified in $100 \%$ phosphoric acid at $70^{\circ} \mathrm{C}$ for $470 \mathrm{~s}$. Repeated analysis of the NBS-19 standard (National Institute of Standards and Technology, NIST SRM 8544) yielded a $\delta^{13} \mathrm{C}$ standard deviation of $0.023 \%$.

\subsection{Data analysis}

For each shell analyzed, samples were exactly positioned along the shell growth trajectory. Each sample was dated according to the number of striae (growth days) between two sampled areas. A calendar date was assigned to each growth stria according to its sequential position relative to the last deposited stria on the ventral margin corresponding to the growth stop (Chauvaud et al., 2005). 
Samples containing several striae would thus yield isotopic ratios that reflect average values for the period spanned by the sampling interval. For each carbonate sample, the day of the median stria was affected to date the sample.

For clarity, we applied a linear interpolation to $\delta^{13} \mathrm{C}_{\text {shell }}$ values of each individual from each temperature conditions (T15, T21 and T25), to calculate the daily $\delta^{13} \mathrm{C}_{\text {shell }}$ series. The $\delta^{13} \mathrm{C}_{\text {shell }}$ results were then averaged each day for each temperature condition $(n=3$ individuals for each treatment).

Between two measured values of $\delta^{13} \mathrm{C}_{\text {DIC }}$, linear interpolation was realized using the relationship observed between algal concentrations $\left(\right.$ cells. $\left.\mathrm{mL}^{-1}\right)$ at the inlet of the tank and $\delta^{13} \mathrm{C}_{\mathrm{DIC}}\left(\delta^{13} \mathrm{C}_{\mathrm{DIC}}=-\right.$ $1.32 \times 10^{-5} \times($ algal concentration at tank inlet $\left.)+0.068 ; \mathrm{R}^{2}=0.68, \mathrm{p}<0.01, \mathrm{n}=23\right)$. Covariation between $\delta^{13} \mathrm{C}_{\text {shell }}$ and $\delta^{13} \mathrm{C}_{\text {DIC }}$ was then calculated for each treatment (T15, T21 and T25).

We used an equation described in McConnaughey et al. (1997) to estimate percentage of metabolic carbon in the shell $\left(\% \mathrm{C}_{\mathrm{M}}\right)$ :

$$
\% \mathrm{C}_{\mathrm{M}}=100 \times\left(\delta^{13} \mathrm{C}_{\text {shell }}-\varepsilon_{\text {cal-b }}-\delta^{13} \mathrm{C}_{\text {DIC }}\right) /\left(\delta^{13} \mathrm{C}_{\mathrm{R}}-\delta^{13} \mathrm{C}_{\text {DIC }}\right)
$$

where $\varepsilon_{\text {cal-b }}$ is the enrichment factor between bicarbonate and calcite independent of temperature in the range of 10 to $40^{\circ} \mathrm{C}$, and equals $1 \%$ (Romanek et al., 1992). The $\delta^{13} \mathrm{C}_{\text {DIC }}$ term refers to the carbon isotope ratio of dissolved inorganic carbon measured in each tank or in the natural environment, and $\delta^{13} \mathrm{C}_{\mathrm{R}}$ refers to the carbon isotope composition of respired carbon as measured from tissue $\left(\delta^{13} \mathrm{C}_{\text {tissue }}\right)$ according to Tanaka et al. (1986) and McConnaughey et al. (1997). Given the lack of consensus on the most relevant tissue for estimating $\delta^{13} \mathrm{C}_{\mathrm{R}}$, we calculated $\mathrm{C}_{\mathrm{M}}$ values from each $\left(\delta^{13} \mathrm{C}\right.$ of muscle, mantle, gills and digestive gland). Values for $\delta^{13} \mathrm{C}_{\text {tissues }}$ declined until July $19^{\text {th }}$, 2011, and then remained constant until the end of the experiment (steady-state period, data not shown). Averaged $\delta^{13} \mathrm{C}_{\text {tissues }}$ values from the steady-state period were used in equation 2 . Under the assumption that they resembled the final metabolized substrate in respective laboratory and field assays, $\delta^{13} \mathrm{C}_{\text {algae }}$ (laboratory experiment) and $\delta^{13} \mathrm{C}$ of particular organic matter $\left(\delta^{13} \mathrm{C}_{\mathrm{POM}}\right.$ for "field" scallops) were also used as $\delta^{13} \mathrm{C}_{\mathrm{R}}$ values.

All statistical analyses were performed using the $\mathrm{R}$ software package ( $\mathrm{R}$ development Core Team, 2005). Comparison of data used ANOVA or Kruskal-Wallis tests if assumptions of normality (Shapiro-Wilk test) or homogeneity of variances (Bartlett test) were in question. For pairwise comparisons, Student tests were applied or Wilcoxon tests in cases where assumptions of normality or homogeneity of variances were not respected. Because $\delta^{13} \mathrm{C}_{\text {shell }}$ values did not exhibit normality, Kendall correlations tests were used to evaluate the correlations between $\delta^{13} \mathrm{C}_{\text {shell }}$ variations between each temperature conditions and $\delta^{13} \mathrm{C}_{\text {shell }}$ and $\delta^{13} \mathrm{C}_{\mathrm{DIC}}$ variations. 


\section{Results}

\subsection{Experimental conditions}

Microalgal quantity distributed in each tank was scaled back during the experiment (from $33.2 \times 10^{4}$ to $5.9 \times 10^{4}$ cells. $\mathrm{mL}^{-1}$; Fig. $2 \mathrm{~B}$ ) to compensate for fewer scallops in tanks due to sampling during the experiment. The average microalgal concentrations ( \pm S.D.) in the tanks during the experiment were $4.3 \times 10^{4} \pm 1.6 \times 10^{4}, 3.0 \times 10^{4} \pm 1.4 \times 10^{4}$ and $3.3 \times 10^{4} \pm 1.3 \times 10^{4}$ cells. $\mathrm{mL}^{-1}$ for $\mathrm{T} 15$, T21 and T25 treatments, respectively (Fig. 2B). Quantity of algae distributed differed significantly among treatments (Kruskal-Wallis: $\mathrm{p}<0.01$ ).

The microalgal carbon isotopic ratio $\left(\delta^{13} \mathrm{C}_{\text {algae }}\right)$ remained stable throughout the experiment, and showed no differences among tanks (ANOVA: $\mathrm{p}=0.87$ ). The T15 and T25 treatments exhibited $\delta^{13} \mathrm{C}_{\text {algae }}$ values of $-54.0 \pm 1.4 \%$ (the two tanks shared the same algae source), while the T21 treatment gave $\delta^{13} \mathrm{C}_{\text {algae }}$ values of $-53.7 \pm 1.7 \%$.

Values of $\delta^{13} \mathrm{C}_{\mathrm{DIC}}$ remained relatively stable during the first part of the experiment and then increased sporadically after July $7^{\text {th }}$, 2011, once temperatures had stabilized in all treatments (Fig. 2C). Values for $\delta^{13} \mathrm{C}_{\mathrm{DIC}}$ ranged from $-4.3 \%$ to $0.07 \%$ and did not vary significantly between treatments (ANOVA: $\mathrm{p}=0.72$ ).

\subsection{Shell growth}

Total shell growth at the end of the experiment reached $7.1 \pm 2.0 \mathrm{~mm}, 7.1 \pm 0.9 \mathrm{~mm}$ and $3.5 \pm$ $1.2 \mathrm{~mm}$ (average \pm S.D., $\mathrm{n}=3$ ) for T15, T21 and T25 treatments, respectively and $44.4 \pm 3.5 \mathrm{~mm}$ for "field" scallops from early March to October $24^{\text {th }}, 2011$. Daily growth rate averages during growth periods were $112.5 \pm 30.0 \mu \mathrm{m} \cdot$ day $^{-1}, 99.9 \pm 34.7 \mu \mathrm{m}$ day $^{-1}, 92.1 \pm 29.5 \mu \mathrm{m}_{\text {day }}{ }^{-1}$ and $192.2 \pm 62.7$ $\mu$ m.day ${ }^{-1}$ for T15, T21, T25 treatments and "field" scallops, respectively. Scallops in the T15 and T21 treatments grew until the end of the experiment (August 15 ${ }^{\text {th }}$ and August 13 ${ }^{\text {th }}, 2011$, respectively), whereas scallops in the T25 treatment ceased to grow (by the latest) on July $11^{\text {th }}, 2011$.

3.3. Carbon isotopic composition of soft tissues and shells 
Steady-state conditions between tissues and food resulted in $\delta^{13} \mathrm{C}_{\text {tissues }}$ values that differed significantly among tissue types, regardless of temperature (ANOVA: $\mathrm{p}<0.01$ ). These variations followed the general pattern of $\delta^{13} \mathrm{C}_{\text {digestive gland }}<\delta^{13} \mathrm{C}_{\text {gills }}<\delta^{13} \mathrm{C}_{\text {mantle }}<\delta^{13} \mathrm{C}_{\text {muscle }}$ (Table 1). Gills and digestive gland tissues also exhibited significantly lower $\delta^{13} \mathrm{C}$ for scallops in the T25 treatment, relative to values for scallops in the two other treatments (Kruskal-Wallis: $\mathrm{p}<0.01$ ). Muscle and mantle tissues had similar $\delta^{13} \mathrm{C}$ values regardless of temperature condition (ANOVA: $\mathrm{p}_{\text {muscle }}=0.17$, $\mathrm{p}_{\text {mantle }}=0.07 ;$ Table 1$)$.

Prior to the application of controlled experimental conditions (May $31^{\text {st }}, 2011$ ), $\delta^{13} \mathrm{C}_{\text {shell }}$ stabilized at mean values of $0.8 \pm 0.3 \%$ o $(n=9)$ (Fig. 3). At the beginning of the experiment, $\delta^{13} \mathrm{C}_{\text {shell }}$ values start to decrease for all scallops. Minimum values of $-5.3 \pm 0.9 \%$ (T15), $-5.5 \pm 0.6 \%$ (T21) and $-6.9 \pm 0.1 \%$ o $(\mathrm{T} 25)$ occurred from June $25^{\text {th }}$ and $29^{\text {th }}$ for all treatments. Shells appear to have reached steady-state after 26 to 30 days. After this point, both $\delta^{13} \mathrm{C}_{\text {shell }}$ and $\delta^{13} \mathrm{C}_{\mathrm{DIC}}$ values increased in each treatment until the end (Fig. 3). During the steady-state period (from June $17^{\text {th }}$ to August $16^{\text {th }}$, 2011 for T15 and from June $19^{\text {th }}$ to August $16^{\text {th }}, 2011$ for T21), $\delta^{13} \mathrm{C}_{\text {shell }}$ variation from the T15 treatment resembled that of the T21 treatment $(r=0.49, \mathrm{p}<0.01)$. Values for $\delta^{13} \mathrm{C}_{\text {shell }}$ and $\delta^{13} \mathrm{C}_{\text {DIC }}$ also covaried in the T15 $(\mathrm{r}=0.63, \mathrm{p}<0.01)$ and $\mathrm{T} 21$ treatments $(\mathrm{r}=0.36, \mathrm{p}<0.01)$.

\subsection{Metabolic contribution}

Metabolic carbon incorporated into shell carbonate was calculated from equation 2 (McConnaughey et al., 1997) using values recorded from July $19^{\text {th }}, 2011$ to August $16^{\text {th }}, 2011$, when $\delta^{13} \mathrm{C}_{\text {tissues }}$ reached steady-state relative to the ${ }^{13} \mathrm{C}$ depleted food source $\left(\delta^{13} \mathrm{C}_{\text {algae }}\right)$. The contribution of metabolic carbon $\left(\mathrm{C}_{\mathrm{M}}\right)$ to shell carbonate varied between $4.3 \pm 0.9 \%$ and $6.8 \pm 2.5 \%$, respectively, measured from $\delta^{13} \mathrm{C}_{\text {digestive gland }}$ and $\delta^{13} \mathrm{C}_{\text {muscle }}$ as proxies for $\delta^{13} \mathrm{C}_{\mathrm{R}}$ (Table 1). Estimation of $\mathrm{C}_{\mathrm{M}}$ from different reference tissues did not significantly differ according to experimental conditions (ANOVA: $\mathrm{p}=0.19$ for $\mathrm{T} 15$ and $\mathrm{p}=0.55$ for $\mathrm{T} 21$; Table 1 ). $\mathrm{C}_{\mathrm{M}}$ calculated from different tissue types also did not differ significantly among different temperature conditions (Student tests: $\mathrm{p}_{\text {muscle }}=0.61$, $\mathrm{p}_{\text {mantle }}=0.70, \mathrm{p}_{\text {gills }}=0.72, \mathrm{p}_{\text {digestive gland }}=0.67$ and $\left.\mathrm{p}_{\text {algae }}=0.62\right)$. Metabolic carbon contribution estimates from the T25 treatment were not available because shells stopped growing before reaching steady-state conditions with respect to $\delta^{13} \mathrm{C}_{\text {tissues }}$ and $\delta^{13} \mathrm{C}_{\text {algae. }}$ 
3.5. $\delta^{13} \mathrm{C}_{\mathrm{DIC}}$ and $\delta^{13} \mathrm{C}_{\text {shell }}$ values from the natural environment

In $2011, \delta^{13} \mathrm{C}_{\text {DIC }}$ measured at Lanvéoc reached their lowest values in winter (minimum of - $0.6 \%$ on $1 \mathrm{March}$ ), then increased (with some variation) to reach maximum values on 26 May (1.8\%). Values then slowly decreased during summer and autumn but did not reach 0\%o (Fig. 4).

$\delta^{13} \mathrm{C}_{\text {shell }}$ of the 3 "field" scallops slightly decreased, from $0.4 \%$ in March 2011 to $-0.7 \%$ in October 2011, with some variation (Fig. 4).

\section{Discussion}

During periods of active growth, mollusk shells record variations in environmental conditions such as food sources or dissolved inorganic carbon (Wilbur and Saleuddin, 1983; McConnaughey and Gillikin, 2008). During the experiment described here, minimum P. maximus shell growth of 2.1 mm (over 33 days) was observed in the T25 treatment. This rate created enough material to record experimental conditions.

4.1. Carbon sources for shell carbonate under controlled conditions

Shell carbon mostly originates from seawater DIC, as shown by the significant correlation between $\delta^{13} \mathrm{C}_{\text {shell }}$ and $\delta^{13} \mathrm{C}_{\text {DIC }}$ (Fig. 3). Poulain et al. (2010) and Beirne et al. (2012) also reported covarying $\delta^{13} \mathrm{C}_{\text {shell }}$ and $\delta^{13} \mathrm{C}_{\text {DIC }}$ values. Values for $\delta^{13} \mathrm{C}_{\text {shell }}$ more closely resembled those of $\delta^{13} \mathrm{C}_{\text {DIC }}$ than those of $\delta^{13} \mathrm{C}_{\text {algae }}$. For example, $\delta^{13} \mathrm{C}_{\text {shell }}$ did not fall below $-8 \%$ whereas the average $\delta^{13} \mathrm{C}_{\text {algae }}$ was $-54 \%$. The proportion of metabolic carbon using $\delta^{13} \mathrm{C}_{\text {tissues }}$ as estimate of $\delta^{13} \mathrm{C}_{\mathrm{R}}$, ranged from 4.3 $\pm 0.9 \%$ to $6.8 \pm 2.5 \%$. These values, established under controlled conditions, resemble previously reported results from $P$. maximus in the natural environment (Lorrain et al., 2004) and from other marine bivalves (Gillikin et al., 2005; Gillikin et al., 2006; Poulain et al., 2010; Beirne et al., 2012). Studies by Gillikin et al. (2007; 2009) on Mercenaria mercenaria (marine bivalve) and Pyganodon cataracta (freshwater bivalve) however, did not find similar low values for metabolic carbon contribution to shell. These authors estimated metabolic carbon contribution ranging from 5 to $37 \%$ 
and 15 to $35 \%$ for $M$. mercenaria and $P$. cataracta, respectively and ascribed their findings to ontogenetic effects, wherein larger shells incorporated greater relative proportions of metabolic carbon (Gillikin et al., 2007; Gillikin et al., 2009). The bivalves used in this study were juveniles (1 year old) and thus were not subject to similar ontogenetic effects. P. maximus $\delta^{13} \mathrm{C}_{\text {shell }}$ could serve as a proxy for environmental $\delta^{13} \mathrm{C}_{\mathrm{DIC}}$, but the influence of respired $\mathrm{CO}_{2}$ and other processes complicates interpretation of $\delta^{13} \mathrm{C}_{\text {shell }}$ variation.

As previously shown by Chauvaud et al. (2011) and Owen et al. (2002a), and demonstrated by our experiment, temperature does not appear to strongly influence $\delta^{13} \mathrm{C}_{\text {shell }}$ over a 15 to $21^{\circ} \mathrm{C}$ range. Values for $\delta^{13} \mathrm{C}_{\text {shell }}$ varied independently of temperature (Fig. 3). P. maximus may consume more as temperature increases (Laing, 2000), thus respiring more, and making more $\mathrm{CO}_{2}$ available for calcification. Metabolic oxygen demand in scallops also increases with seawater temperature, again increasing the amount of respired $\mathrm{CO}_{2}$. In this study, percentage of metabolic carbon integrated into shell carbonate did not differ significantly according to temperature, regardless of the tissue type used to estimate $\mathrm{C}_{\mathrm{M}}$ (Table 1). During an increase in temperature however, the minimum $\delta^{13} \mathrm{C}_{\text {shell }}$ value did differ according to temperature condition. Stronger metabolism and greater integration of metabolic carbon into carbonates with increasing temperature may explain these aspects of the data.

Integration of DIC and/or metabolic carbon from food source into shell carbonate was rapid, and reached steady-state after 26 to 30 days. Using the same experimental design, Poulain et al. (2010) found a similar trends among Manila clams. Extrapallial fluid directly incorporates DIC and uses it to precipitate calcite, whereas respired $\mathrm{CO}_{2}$ can derive from several metabolic processes occurring in tissues and hemolymph (Wilbur and Saleuddin, 1983; McConnaughey and Gillikin, 2008). The incorporation delay is consistent with tissue turnover observed among bivalves (Paulet et al., 2006). At the beginning of the experiment, carbonate precipitation may have rapidly assimilated ${ }^{13} \mathrm{C}$ depleted DIC, mixing it with respired $\mathrm{CO}_{2}$ from food ingested prior to the experiment. Once $\delta^{13} \mathrm{C}_{\text {tissues }}$ reached steady-state with $\delta^{13} \mathrm{C}_{\text {algae }}$ (50 days after the start of the experiment), metabolic carbon incorporated into calcite (less than 10\%) assumed the $\delta^{13} \mathrm{C}$ composition of the phytoplankton food source given during the experiment.

4.2. Input of the integration of experimental and natural environment data

Data from scallops reared under laboratory conditions and from scallops in their natural environment confirm the influence of $\delta^{13} \mathrm{C}_{\text {DIC }}$ and $\delta^{13} \mathrm{C}$ of food sources $\left(\delta^{13} \mathrm{C}_{\text {food }}\right)$ on $\delta^{13} \mathrm{C}_{\text {shell }}$ values. 
$\mathrm{C}_{\mathrm{M}}$ reached values of around $10 \%$ (from 4.3 to $6.8 \%$ under experimental conditions and from 1.9 to $16.6 \%$ in the natural environment; Fig. 6), as predicted by the "respiratory gas exchange model" described in McConnaughey et al. (1997). Both environmental factors (temperature, $\mathrm{pH}$ and stable carbon isotopic composition of food) and physiological parameters (metabolism, shell growth rate and ontogeny) influence $\delta^{13} \mathrm{C}_{\text {shell }}$ variation.

The shift in stable carbon isotopic composition of food provided the opportunity to study its effect on the predicted equilibrium between calcium carbonate and ambient bicarbonate (Fig. 5A). Data from "field" scallops showed an offset (from equilibrium) of $1.7 \pm 0.6 \%$ while those from scallops reared under experimental conditions showed an offset of $2.5 \pm 0.5$ and $3.2 \pm 0.9 \%$ for individuals maintained at temperatures of 15 and $21^{\circ} \mathrm{C}$, respectively. Differences between these values were significant (pairwise Wilcoxon: "field"/T15: $p<0.001$, "field"/T21: $p<0.001$ and T15/T21: $\mathrm{p}<0.001)$. This indicates that a $-21 \%$ to $-54 \%$ shift in the stable carbon isotopic composition of food sources causes the $1.7 \%$ offset from the predicted equilibrium to shift to $2.5 \%$ o at $15^{\circ} \mathrm{C}$ and to $3.2 \%$ at $21^{\circ} \mathrm{C}$. Even given covarying relations between $\delta^{13} \mathrm{C}_{\text {shell }}$ and $\delta^{13} \mathrm{C}_{\text {DIC }}$ observed from T15 and T21 experimental data, the steady-state conditions among $\delta^{13} \mathrm{C}$ values of food, DIC, tissues and shell coincide with offset values significantly different from zero, thus demonstrating the significant influence of $\delta^{13} \mathrm{C}_{\text {food }}$ on $\delta^{13} \mathrm{C}_{\text {shell }}$ values. The greater similarity of $\delta^{13} \mathrm{C}_{\text {shell }}$ values to those of $\delta^{13} \mathrm{C}_{\mathrm{DIC}}$, rather than to those of $\delta^{13} \mathrm{C}_{\text {food }}$ indicates a relatively low metabolic carbon contribution to shell carbon. The offset difference observed between data from the 15 and $21^{\circ} \mathrm{C}$ laboratory temperature conditions could result from a slightly higher carbon metabolic contribution documented in the T21 data.

The difference in offset observed for the "field" and experimental data could also reflect growth rate differences. Plots of daily growth rate versus offset in "field" scallop data (Fig. 5B, open circles), show a low growth rate group with an offset of $0.5 \%$, and a high growth rate group with an offset of $1.8 \%$. In the natural environment, low growth rates correspond to low food level and low temperature conditions, whereas high growth rates reflect the opposite (Fig. 6). A 3\%o offset for experimental scallop shell data is therefore not consistent with growth rate variation.

Food supply and temperature effects may introduce annual variation in organic carbon incorporation $\left(\mathrm{C}_{\mathrm{M}}\right)$ values in "field" scallop data. Shell growth recommences at the end of the winter, in tandem with an increase in organic carbon contribution to shell. At that time of the year, $\mathrm{C}_{\mathrm{M}}$ in the shell is around $2 \%$. As food availability and temperatures increase, $\mathrm{C}_{\mathrm{M}}$ also rises progressively (Fig. 6). From June to October, $\mathrm{C}_{\mathrm{M}}$ oscillated slightly around $12 \%$ (Fig. 6) but did not decrease, even once 
surface temperatures began to drop. Surprisingly, $\mathrm{C}_{M}$ fell to values of $2.9 \%$ in early May, when shell growth rate declined with the onset of a phytoplankton bloom. Chauvaud et al. (1998) and Lorrain et al. (2000) have previously documented declines in P. maximus shell growth during spring blooms, suggesting that it reflects a reduction in feeding. Spring $C_{M}$ values approaching zero support these earlier observations and interpretations.

According to Chatterjee et al. (2013), the 2011 seasonal variation in food sources for benthic filter-feeders in the Bay of Brest (Lanvéoc) divides into four periods. These include (1) periods of very low food concentration from January to the end of February and from mid-October to the end of December, (2) a period when microphytobenthos bloomed and phytoplankton were present, from March to the end of April, (3) a period during which phytoplankton bloomed and microphytobenthos were still productive, from May to the end of May, and (4) a period when only phytoplankton were present, from June to mid-October (Fig. 6). The integration of metabolic carbon into carbonate varied significantly (Kruskal-Wallis: $\mathrm{p}<0.01$ ), according to the four defined periods, regardless of value types used to estimate $\delta^{13} \mathrm{C}_{\mathrm{R}}$ values (including $\delta^{13} \mathrm{C}_{\text {muscle }}$ for scallops sampled in 2000 by Lorrain et al. (2002), or $\delta^{13} \mathrm{C}_{\mathrm{POM}}$ sampled in 2011; see Fig. 6 legend for details). This variation probably reflects seasonal growth trends for P. maximus described by Guarini et al. (2011). These authors interpreted winter as a period of limited food availability, when $P$. maximus suspends morphodynamic development and reduces metabolic activity. Spring represents a period of high food availability and increased metabolism for the organism (Pazos et al., 1997; Guarini et al., 2011). A transition phase occurs between these two periods, in which the organism's feeding and growth shift to accommodate changes in metabolic activity. When integrated with the equation of McConnaughey et al. (1997) these different phases give:

$$
\delta^{13} \mathrm{C}_{\text {shell }}=\left(\delta^{13} \mathrm{C}_{\text {food }} \times \mathrm{C}_{\mathrm{M}}\right)+\left(\delta^{13} \mathrm{C}_{\mathrm{DIC}} \times\left(100-\mathrm{C}_{\mathrm{M}}\right)\right)+1
$$

The consequences for $\delta^{13} \mathrm{C}_{\text {shell }}$ values were that $\delta^{13} \mathrm{C}_{\text {DIC }}$ equaled $\delta^{13} \mathrm{C}_{\text {shell }}$ measured at the end of the winter, minus $1 \%$ when the growth recommenced, and $\mathrm{C}_{\mathrm{M}}$ tended towards $0 \%$. This demonstrates that $C_{M}$ values should be estimated at the end of the transition phase, once shells reach steady-state.

\section{Conclusion}

This study used laboratory experiments and data from the natural environment to calibrate and interpret $P$. maximus as a paleoenvironmental proxy. Data from laboratory experiment allowed us to 
study seasonal variation in $\delta^{13} \mathrm{C}_{\text {shell }}$ values and provide further information on previously proposed relation between growth rate and $\delta^{13} \mathrm{C}_{\text {shell }}$ (Lorrain et al., 2004). Uptake of the strongly depleted food source demonstrated how carbonates values diverge from predicted equilibrium values with ambient bicarbonate. In contrast to the findings of Chauvaud et al. (2011), data from this study demonstrated that $\delta^{13} \mathrm{C}_{\text {shell }}$ values from scallops can serve as accurate proxy values for $\delta^{13} \mathrm{C}_{\mathrm{DIC}}$, when measured from calcite forming during the period when recovery in shell growth occurs. Moreover, Chauvaud et al. (2011) did identify similar patterns when they removed the ontogenetic signal from $\delta^{13} \mathrm{C}_{\text {shell }}$ values measured from large $P$. maximus individuals. The reassessed $\delta^{13} \mathrm{C}_{\text {shell }}$ values presented by Chauvaud et al. (2011), referred to as $\delta^{13} \mathrm{C}_{\text {shell detrended }}$ had similar annual minima, confirming that this value can serve as a proxy for $\delta^{13} \mathrm{C}_{\mathrm{DIC}}$.

Ecophysiological studies can also benefit from $\delta^{13} \mathrm{C}_{\text {shell }}$ information. Seasonal variation in $\mathrm{C}_{\mathrm{M}}$ from the age class I scallops (one year old) analyzed here can now be used to reinterpret $\delta^{13} \mathrm{C}_{\text {shell }}$ data from older individuals.

\section{Acknowledgements}

The project was supported by the French program COMANCHE (Agence Nationale de la Recherche, ANR-2010-STRA-010), the French program CHIVAS (Agence Nationale de la Recherche, ANR-Blanc) and the Natural Environment Research Council (grant NE/G000018/1 to LSP). We thank the Service d'Observation en Milieu Littoral, INSU-CNRS, station de Brest (http://somlit.epoc.u-bordeaux1.fr/fr/) for providing temperature and $\delta^{13} \mathrm{C}_{\mathrm{POM}}$ data. The authors also thank all the staff of the IFREMER shellfish laboratory at Argenton, the Tinduff scallop hatchery for providing juvenile scallops, and Anne Lorrain, who contributed scallop data as well as helpful comments and feedback. We are also grateful to the entire CHIVAS team for their perseverance that enabled the full survey at Lanvéoc in 2011. We are grateful to Dr. J. N. Sutton for English and editing improvements. V. Marchais was supported by a doctoral grant from the Université de Bretagne Occidentale.

\section{References}


Arthur M. A., Williams D. F. and Jones D. S. (1983) Seasonal temperature-salinity changes and thermocline development in the mid-Atlantic Bight as recorded by the isotopic composition of bivalves. Geology 11, 655-659.

Beirne E. C., Wanamaker Jr A. D. and Feindel S. C. (2012) Experimental validation of environmental controls on the $\delta^{13} \mathrm{C}$ of Arctica islandica (ocean quahog) shell carbonate. Geochim. Cosmochim. Acta 84, 395-409.

Butler P. G., Wanamaker Jr A. D., Scourse J. D., Richardson C. A. and Reynolds D. R. (2011) The stability of shell $\delta^{13} \mathrm{C}$ with respect to biological age in mature specimens of the long-lived bivalve Arctica islandica. Palaeogeogr. Palaeoclimatol. Palaeocol. 302, 21-30.

Chatterjee A., Klein C., Naegelen A., Claquin P., Masson A., Legoff M., Amice E., L'Helguen S., Chauvaud L. and Leynaert A. (2013) Comparative dynamics of pelagic and benthic microalgae in a coastal ecosystem. Est. Coast. Shelf Sci. 133, 67-77.

Chauvaud L., Thouzeau G. and Paulet Y.-M. (1998) Effects of environmental factors on the daily growth rate of Pecten maximus juveniles in the Bay of Brest (France). J. Exp. Mar. Bio. Ecol. 227, 83-111.

Chauvaud L., Lorrain A., Dunbar R. B., Paulet Y.-M., Thouzeau G., Jean F., Guarini J.-M. and Mucciarone D. (2005) Shell of the Great Scallop Pecten maximus as a high-frequency archive of paleoenvironmental changes. Geochim. Geophy. Geosyst. 6, 1-15.

Chauvaud L., Thébault J., Clavier J., Lorrain A. and Strand Ø. (2011) What's hiding behind ontogenetic $\delta^{13} \mathrm{C}$ variations in mollusk shells? New insights from the Great Scallop (Pecten maximus). Estuar. Coast. 34, 211-220.

Chauvaud L., Patry Y., Jolivet A., Cam E., Le Goff C., Strand Ø., Charrier G., Thébault J., Lazure P. and Gotthard K. (2012) Variation in size and growth of the great scallop Pecten maximus along a latitudinal gradient. PloS one 7, e37717.

Coplen T. B. (2011) Guidelines and recommended terms for expression of stable isotope ratio and gas ratio measurement results. Rapid Commum. Mass Spectrom. 25, 2538-2560.

Craig H. (1965) Measurement of oxygen isotope paleotemperatures, in: Tongiori, E. (Ed.), Stable isotopes in oceanographic studies and paleotemperatures. Cons. Naz. delle Ric., Spoleto, Italy, pp. 161-182.

Davenport C. B. (1938) Growth lines in fossil pectens as indicators of past climates. J. Paleontol. 12, 514-515. 
Dettman D. L., Reische A. K. and Lohmann K. C. (1999) Controls on the stable isotope composition of seasonal growth bands in aragonitic fresh-water bivalves (Unionidae). Geochim. Cosmochim. Acta 63, 1049-1057.

Emiliani C. (1966) Isotopic paleotemperatures. Science 154, 851-857.

Epstein S., Buchsbaum R., Lowenstam H. A. and Urey H. C. (1953) Revised carbonate-water isotopic temperature scale. Geol. Soc. Am. Bull. 64, 1315-1326.

Erez J. (1978) Vital effect on stable-isotope composition seen in foraminifera and coral skeletons. Science 273, 199-202.

Furla P., Galgani I., Durand I. and Allemand D. (2000) Sources and mechanisms of inorganic carbon transport for coral calcification and photosynthesis. J. Exp. Biol. 203, 3445-3457.

Geist J., Auerswald K. and Boom A. (2005) Stable carbon isotopes in freshwater mussel shells: environmental record or marker for metabolic activity? Geochim. Cosmochim. Acta 69, 35453554.

Gillikin D. P., De Ridder F., Ulens H., Elskens M., Keppens E., Baeyens W. and Dehairs F. (2005) Assessing the reproducibility and reliability of estuarine bivalve shells (Saxidomus giganteus) for sea surface temperature reconstruction: Implications for paleoclimate studies. Palaeogeogr. Palaeoclimatol. Palaeocol. 228, 70-85.

Gillikin D. P., Lorrain A., Bouillon S., Willenz P. and Dehairs F. (2006) Stable carbon isotopic composition of Mytilus edulis shells: relation to metabolism, salinity, $\delta^{13} \mathrm{C}_{\mathrm{DIC}}$ and phytoplankton. Org. Geochem. 37, 1371-1382.

Gillikin D. P. and Bouillon S. (2007) Determination of ${ }^{18} \mathrm{O}$ of water and ${ }^{13} \mathrm{C}$ of dissolved inorganic carbon using a simple modification of an elemental analyser isotope ratio mass spectrometer: an evaluation. Rapid Commum. Mass Spectrom. 21, 1475-1478.

Gillikin D. P., Lorrain A., Meng L. and Dehairs F. (2007) A large metabolic carbon contribution to the $\delta^{13} \mathrm{C}$ record in marine aragonitic bivalve shells. Geochim. Cosmochim. Acta 71, 2936-2946.

Gillikin D. P., Hutchinson K. A. and Kumai Y. (2009) Ontogenic increase of metabolic carbon in freshwater mussel shells (Pyganodon cataracta). J. Geophys. Res. 114, G01007.

Gonzalez L. A. and Lohmann K. C. (1985) Carbon and oxygen isotopic composition of Holocene reefal carbonates. Geology 13, 811-814. 
Grossman E. L. and Ku T. L. (1986) Oxygen and carbon isotope fractionation in biogenic aragonite: temperature effects. Chem. Geol. 59, 59-74.

Guarini J.-M., Chauvaud L., Cloern J. E., Clavier J., Coston-Guarini J. and Patry Y. (2011) Seasonal variations in ectotherm growth rates: quantifying growth as an intermittent non steady state compensatory process. J. Sea Res. 65, 355-361.

Ingram B. L., Conrad M. E. and Ingle J. C. (1996) Stable isotope and salinity systematics in estuarine waters and carbonates: San Francisco Bay. Geochim. Cosmochim. Acta 60, 455-467.

Killingley J. S. and Berger W. H. (1979) Stable isotopes in a mollusk shell: detection of upwelling events. Science 205, 186-188.

Klein R. T., Lohmann K. C. and Thayer C. W. (1996) $\mathrm{SrCa}$ and ${ }^{13} \mathrm{C} /{ }^{12} \mathrm{C}$ ratios in skeletal calcite of Mytilus trossulus: covariation with metabolic rate, salinity, and carbon isotopic composition of seawater. Geochim. Cosmochim. Acta 60, 4207-4221.

Krantz D. E., Williams D. F. and Jones D. S. (1987) Ecological and paleoenvironmental information using stable isotope profiles from living and fossil molluscs. Palaeogeogr. Palaeoclimatol. Palaeocol. 58, 249-266.

Laing I. (2000) Effect of temperature and ration on growth and condition of king scallop (Pecten maximus) spat. Aquaculture 183, 325-334.

Lorrain A., Paulet Y.-M., Chauvaud L., Savoye N., Nézan E. and Guérin L. (2000) Growth anomalies in Pecten maximus from coastal waters (Bay of Brest, France): relationship with diatom blooms. J. Mar. Biol. Assoc. U. K. 80, 667-673.

Lorrain A., Paulet Y. M., Chauvaud L., Savoye N., Donval A. and Saout C. (2002) Differential $\delta^{13}$ C and $\delta^{15} \mathrm{~N}$ signatures among scallop tissues: implications for ecology and physiology. J. Exp. Mar. Bio. Ecol. 275, 47-61.

Lorrain A., Savoye N., Chauvaud L., Paulet Y. M. and Naulet N. (2003) Decarbonation and preservation method for the analysis of organic $\mathrm{C}$ and $\mathrm{N}$ contents and stable isotope ratios of low-carbonated suspended particulate material. Anal. Chim. Acta 491, 125-133.

Lorrain A., Paulet Y. M., Chauvaud L., Dunbar R., Mucciarone D. and Fontugne M. (2004) $\delta^{13}$ C variation in scallop shells: Increasing metabolic carbon contribution with body size? Geochim. Cosmochim. Acta 68, 3509-3519.

Marin F. and Luquet G. (2004) Molluscan shell proteins. C. R. Acad. Sci. PALEVOL 3, 469-492. 
McConnaughey T. (1989a) ${ }^{13} \mathrm{C}$ and ${ }^{18} \mathrm{O}$ isotopic disequilibrium in biological carbonates. 1. Patterns. Geochim. Cosmochim. Acta 53, 151-162.

McConnaughey T. (1989b) ${ }^{13} \mathrm{C}$ and ${ }^{18} \mathrm{O}$ isotopic disequilibrium in biological carbonates. 2. in vitro simulation of kinetic isotope effects. Geochim. Cosmochim. Acta 53, 163-171.

McConnaughey T. A., Burdett J., Whelan J. F. and Paull C. K. (1997) Carbon isotopes in biological carbonates: respiration and photosynthesis. Geochim. Cosmochim. Acta 61, 611-622.

McConnaughey T. A. and Gillikin D. P. (2008) Carbon isotopes in mollusk shell carbonates. GeoMar. Lett. 28, 287-299.

Mook W. G. and Vogel J. C. (1968) Isotopic equilibrium between shells and their environment. Science 159, 874-875.

Mook W. G. (1971) Paleotemperatures and chlorinities from stable carbon and oxygen isotopes in shell carbonate. Palaeogeogr. Palaeoclimatol. Palaeocol. 9, 245-263.

O'Neil J. R., Clayton R. N. and Mayeda T. K. (1969) Oxygen isotope fractionation in divalent metal carbonates. J. Chem. Phys. 51, 5547-5557.

Owen R., Kennedy H. and Richardson C. (2002a) Experimental investigation into partitioning of stable isotopes between scallop (Pecten maximus) shell calcite and sea water. Palaeogeogr. Palaeoclimatol. Palaeocol. 185, 163-174.

Owen R., Kennedy H. and Richardson C. (2002b) Isotopic partitioning between scallop shell calcite and seawater: effect of shell growth rate. Geochim. Cosmochim. Acta 66, 1727-1737.

Paulet Y.-M., Lucas A. and Gerard A. (1988) Reproduction and larval development in two Pecten maximus (L.) populations from Brittany. J. Exp. Mar. Bio. Ecol. 119, 145-156.

Paulet Y. M., Lorrain A., Richard J. and Pouvreau S. (2006) Experimental shift in diet $\delta^{13}$ C: A potential tool for ecophysiological studies in marine bivalves. Org. Geochem. 37, 1359-1370.

Pazos A. J., Román G., Acosta C. P., Abad M. and Sánchez J. L. (1997) Seasonal changes in condition and biochemical composition of the scallop Pecten maximus L. from suspended culture in the Ria de Arousa (Galicia, N.W. Spain) in relation to environmental conditions. $J$. Exp. Mar. Bio. Ecol. 211, 169-193.

Poulain C., Lorrain A., Mas R., Gillikin D. P., Dehairs F., Robert R. and Paulet Y.-M. (2010) Experimental shift of diet and DIC stable carbon isotopes: Influence on shell $\delta^{13} \mathrm{C}$ values in the Manila clam Ruditapes philippinarum. Chem. Geol. 272, 75-82. 
$\mathrm{R}$ development Core Team (2005) $R$ : a language and environment for statistical computing, $\mathrm{R}$ Foundation for Statistical Computing, Vienna, Austria.

Romanek C. S., Grossman E. L. and Morse J. W. (1992) Carbon isotopic fractionation in synthetic aragonite and calcite: Effects of temperature and precipitation rate. Geochim. Cosmochim. Acta 56, 419-430.

Saout C., Quéré C., Donval A., Paulet Y.-M. and Samain J.-F. (1999) An experimental study of the combined effects of temperature and photoperiod on reproductive physiology of Pecten maximus from the Bay of Brest (France). Aquaculture 172, 301-314.

Schöne B. R., Lega J., Flessa K. W., Goodwin D. H. and Dettman D. L. (2002) Reconstructing daily temperatures from growth rates of the intertidal bivalve mollusk Chione cortezi (northern Gulf of California, Mexico). Palaeogeogr. Palaeoclimatol. Palaeocol. 184, 131-146.

Schöne B. R., Oschmann W., Rössler J., Castro A. D. F., Houk S. D., Kröncke I., Dreyer W., Janssen R., Rumohr H. and Dunca E. (2003) North Atlantic Oscillation dynamics recorded in shells of a long-lived bivalve mollusk. Geology 31, 1037-1040.

Schöne B. R., Fiebig J., Pfeiffer M., Gle $\beta$ R., Hickson J., Johnson A. L., Dreyer W. and Oschmann W. (2005) Climate records from a bivalve Methuselah (Arctica islandica, Mollusca; Iceland). Palaeogeogr. Palaeoclimatol. Palaeocol. 228, 130-148.

Shackleton N. J. (1967) Oxygen isotope analyses and Pleistocene temperatures re-assessed. Nature 215, 15-17.

Shackleton N. J., Wiseman J. D. H. and Buckley H. A. (1973) Non-equilibrium isotopic fractionation between seawater and planktonic foraminiferal tests. Nature 242, 177-179.

Stanton J., Robert J and Dodd J. R. (1970) Paleoecologic techniques: comparison of faunal and geochemical analyses of Pliocene paleoenvironments, Kettleman Hills, California. $J$. Paleontol. 44, 1092-1121.

Swart P. K. (1983) Carbon and oxygen isotope fractionation in scleractinian corals: a review. Earth Sci. Rev. 19, 51-80.

Tanaka N., Monaghan M. C. and Rye D. M. (1986) Contribution of metabolic carbon to mollusc and barnacle shell carbonate. Nature 320, 520-523.

Urey H. C. (1947) The thermodynamic properties of isotopic substances. J. Chem. Soc. 1947, $562-$ 581. 
Utting S. D. and Millican P. F. (1998) The role of diet in hatchery conditioning of Pecten maximus (L).: a review. Aquaculture 165, 167-178.

Vander Putten E., Dehairs F., Keppens E. and Baeyens W. (2000) High resolution distribution of trace elements in the calcite shell layer of modern Mytilus edulis: environmental and biological controls. Geochim. Cosmochim. Acta 64, 997-1011.

Wanamaker A. D., Jr, Kreutz K. J., Borns Jr H. W., Introne D. S., Feindel S., Funder S., Rawson P. D. and Barber B. J. (2007) Experimental determination of salinity, temperature, growth, and metabolic effects on shell isotope chemistry of Mytilus edulis collected from Maine and Greenland. Paleoceanography 22, 1-12.

Wilbur K. M. and Saleuddin A. S. M. (1983) Shell Formation, in: Saleuddin, A.S.M., Wilbur, K.M. (Eds.), The Mollusca. Academic Press, Inc., pp. 235-287. 


\section{Figure legends}

Figure 1: Location of Tinduff bivalve hatchery, Sainte-Anne du Portzic where Pecten maximus scallops were raised for their first year, Argenton shellfish laboratory where the experiment was conducted, and of the Lanvéoc site where "field" scallops were collected.

Figure 2: Seawater parameters recorded for the three treatments during the experiment: (A) seawater temperatures into the three tanks, (B) number of algal cells measured whithin (solid lines) and at the inlet of the experimental tanks (dashed lines), and (C) $\delta^{13} \mathrm{C}_{\mathrm{DIC}}$ interpolated (dashed lines) between measured values (solid points) from linear regression $\left(\delta^{13} \mathrm{C}_{\mathrm{DIC}}=-1.32 \times 10^{5} \times(\right.$ algal concentration at tank inlet $\left.)+0.068, \mathrm{R}^{2}=0.68, \mathrm{p}<0.01, \mathrm{n}=23\right)$. Light grey: $15^{\circ} \mathrm{C}$ treatment $(\mathrm{T} 15)$, grey: $21^{\circ} \mathrm{C}$ treatment (T21), black: $25^{\circ} \mathrm{C}$ treatment (T25). (1): beginning of laboratory experiment, (2): beginning of water temperature increase, (3): water temperature stable for T21, (4): water temperature stable for T25, (5): end of experiment.

Figure 3: Average $\delta^{13} \mathrm{C}_{\text {shell }} \pm$ S.D. $(\mathrm{n}=3$ individuals per treatment and $\mathrm{n}=9$ before onset of experimental temperature conditions) and $\delta^{13} \mathrm{C}_{\text {DIC }}$ inside the tanks during the experiment. Dashed line: $\delta^{13} \mathrm{C}_{\text {shell }}$ of scallops under natural conditions, solid lines: $\delta^{13} \mathrm{C}_{\text {shell }}$ from laboratory experiment, dotted lines: $\delta^{13} \mathrm{C}_{\mathrm{DIC}}$. Light grey: $15^{\circ} \mathrm{C}$ treatment (T15), grey: $21^{\circ} \mathrm{C}$ treatment $(\mathrm{T} 21)$, black: $25^{\circ} \mathrm{C}$ treatment (T25). Arrows: end of shell growth. (1): beginning of laboratory experiment, (2): beginning of water temperature increase, (3): water temperature stable for T21, (4): water temperature stable for T25, (5): end of experiment.

Figure 4: $\delta^{13} \mathrm{C}_{\text {shell }}$ values for three "field" scallops growing throughout the year 2011 along with surface seawater $\delta^{13} \mathrm{C}_{\text {DIC }}$ at Lanvéoc station. The three "field" scallops were collected on October $24^{\text {th }}, 2011$. Black solid circles: $\delta^{13} \mathrm{C}_{\text {shell }}$ of "field" scallops, grey dashed line: $\delta^{13} \mathrm{C}_{\text {DIC. }}$ Arrows: end of shell growth.

Figure 5: (A) $\delta^{13} \mathrm{C}_{\text {shell }}$ versus $\delta^{13} \mathrm{C}_{\mathrm{DIC}}$ values plotted relative to the empirically determined relationship between inorganic calcite and bicarbonate (black line; Romanek et al., 1992). (B) Isotopic fractionation between calcite and DIC versus daily growth rate. Open circles: "field" scallops, solid circles: laboratory experiment scallops during steady-state period (from July $19^{\text {th }}$, 
2011 to August 16 $\left.{ }^{\text {th }}, 2011\right)$, light grey: T15 treatment, grey: T21 treatment, crosses: centre of each scatter plot on graph A.

Figure 6: Field scallop data compiled in order to estimate percentage of organic carbon integrated into the shell over four periods of the year (2011), defined according to variation in food sources: (1) periods of very low food concentration, from January to the end of February and from mid-October to the end of December, (2) period when microphytobenthos bloomed and phytoplankton were present, from March to the end of April, (3) period during which phytoplankton bloomed and microphytobenthos were still productive, from May to the end of May and (4) period when only phytoplankton were present, from June to mid-October. (a) Chlorophyll a data (microphytobenthos and phytoplankton) sampled at Lanvéoc in 2011 (Chatterjee et al., 2013). (b) Daily growth rate for class I great scallop shells (grey line, average \pm confidence interval at $5 \%, \mathrm{n}=22$ individuals) sampled October $24^{\text {th }}, 2011$ at Lanvéoc, sea surface temperature (dashed grey line) measured at Sainte-Anne du Portzic (see Fig. 1), data provided by Marel buoy (IUEM-IFREMER/UBO/INSUCNRS, agreement $n^{\circ} 11 / 2-210922$ ) and $C_{M}$ (black line, average \pm S.D.) estimated by equation 2 using $\delta^{13} \mathrm{C}_{\text {muscle }}$ as a proxy for $\delta^{13} \mathrm{C}_{\mathrm{R}}$. (c) Surface water $\delta^{13} \mathrm{C}_{\mathrm{DIC}}$ and $\delta^{13} \mathrm{C}_{\text {shell }}$ of great scallops (age class I; average \pm S.D.) sampled in 2011 at Lanvéoc (from Fig. 4) for each of the four periods. (d) $\delta^{13} \mathrm{C}_{\text {muscle }}$ (annual average \pm S.D.) of age class III great scallop sampled at Roscanvel (Bay of Brest) in 2000 (data from Lorrain et al., 2002). (e) $\delta^{13} C_{\mathrm{POM}}$ (average \pm S.D.) of sub-surface water sampled at Sainte-Anne du Portzic (Fig. 1) for each of the four periods (data from Service d'Observation en Milieu Littoral (SOMLIT), INSU-CNRS, station de Brest). (f) $\mathrm{C}_{M}$ (average \pm S.D.) estimated from equation 2 using $\delta^{13} \mathrm{C}_{\mathrm{DIC}}$ and $\delta^{13} \mathrm{C}_{\text {shell }}$ from 2011 and $\delta^{13} \mathrm{C}_{\text {muscle }}$ (as proxy for $\delta^{13} \mathrm{C}_{\mathrm{R}}$ ) from 2000 . (g) $\mathrm{C}_{\mathrm{M}}$ (average \pm S.D.) estimated from equation 2 using $\delta^{13} \mathrm{C}_{\mathrm{DIC}}, \delta^{13} \mathrm{C}_{\text {shell }}$ and $\delta^{13} \mathrm{C}_{\mathrm{POM}}$ (as proxy for $\delta^{13} \mathrm{C}_{\mathrm{R}}$ ) from 2011. White boxes: data, grey boxes: estimates from data. 


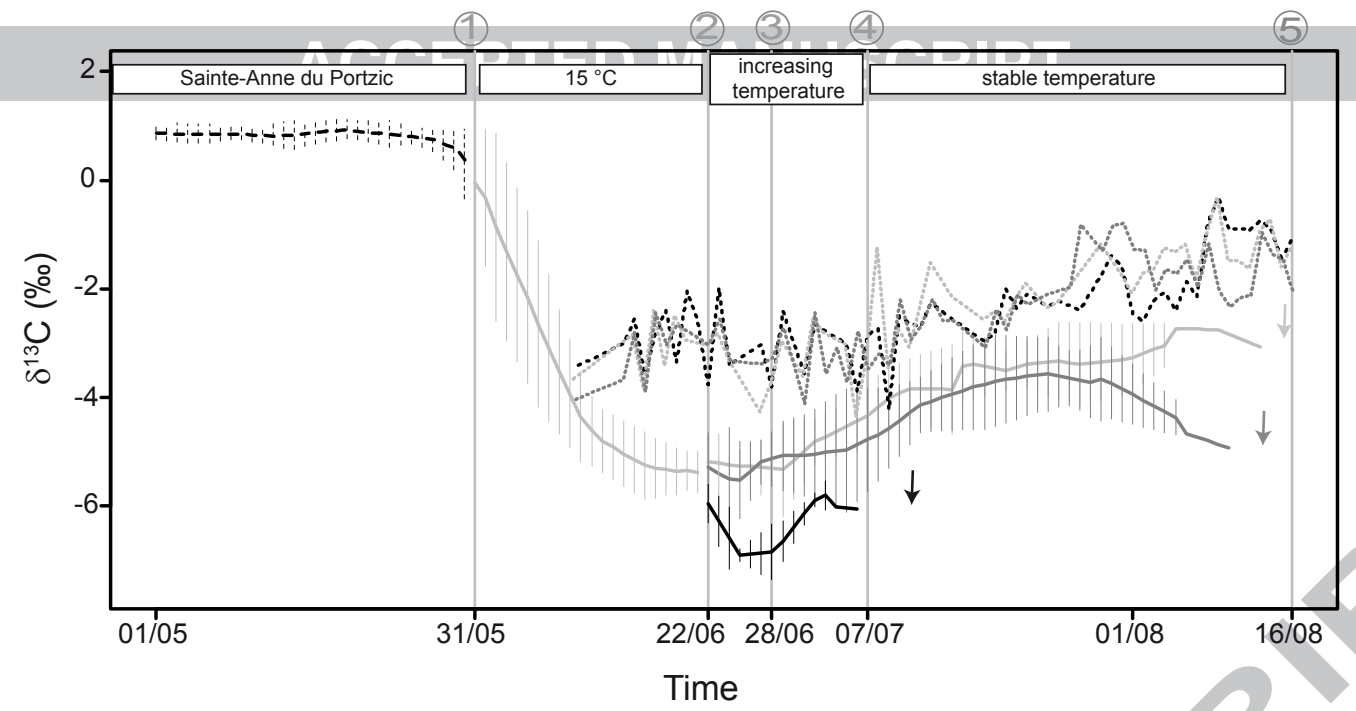




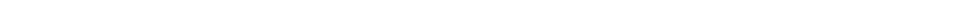



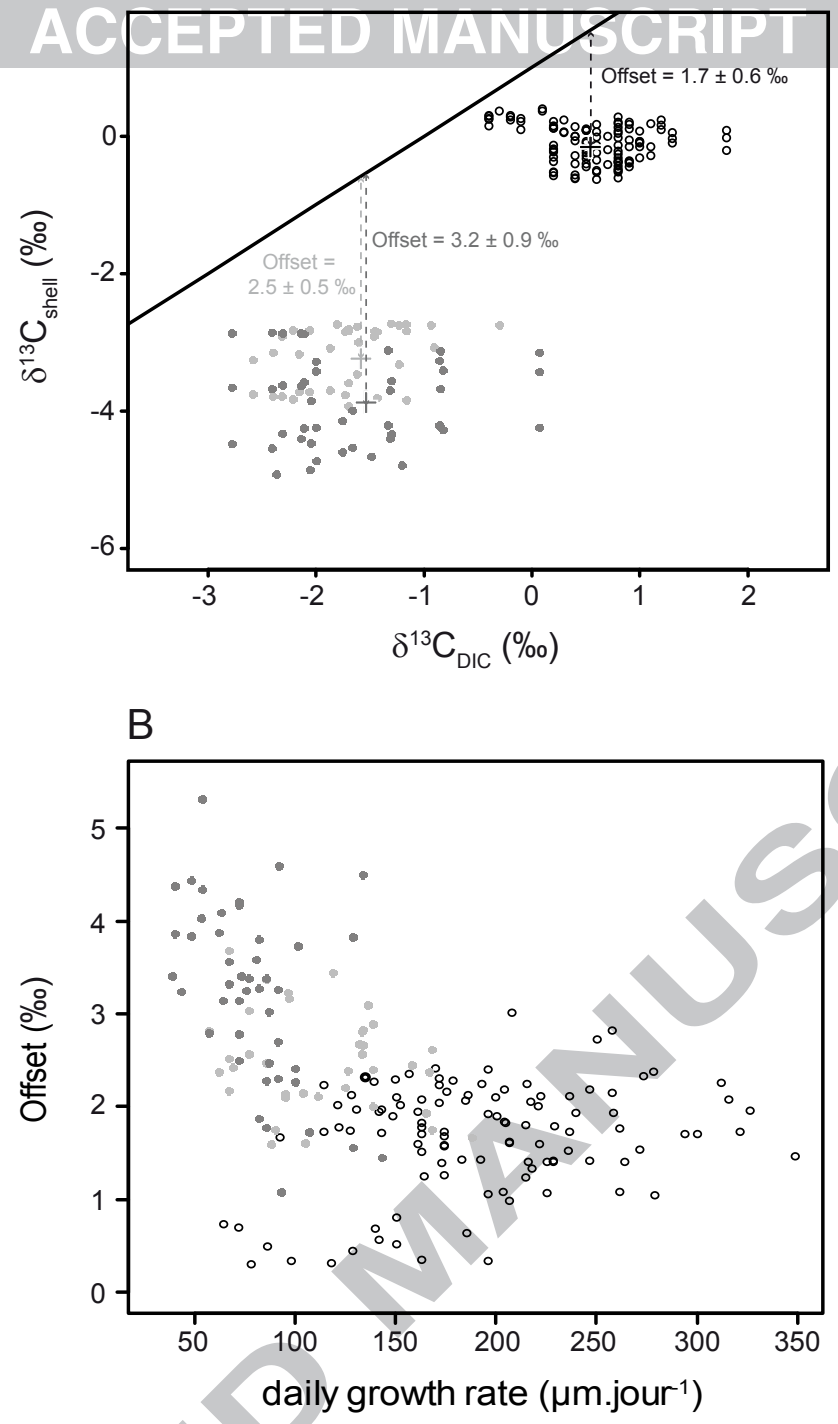
Annual average ( \pm S.D.) $\quad$ Year Ref.

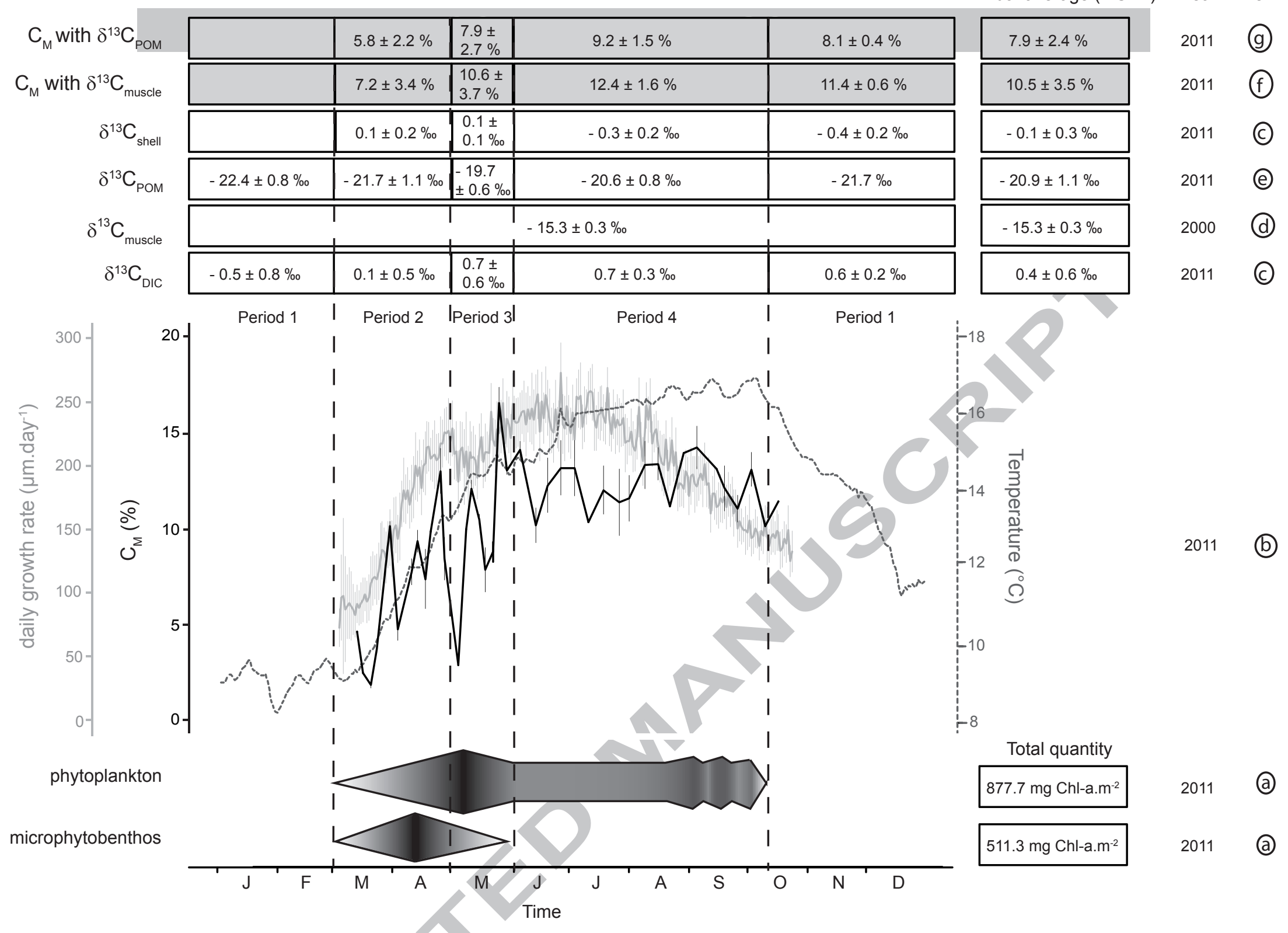


Table 1: Average carbon isotopic ratio $\left(\delta^{13} \mathrm{C}\right)$ in four scallop tissues (muscle, mantle, gills and digestive gland) and phytoplankton for each treatment, and contribution (in percentage) of metabolic carbon $\left(\% \mathrm{C}_{\mathrm{M}}\right)$ in $\delta^{13} \mathrm{C}_{\text {shell }}$ calculated with $\delta^{13} \mathrm{C}_{\text {tissues }}$ and $\delta^{13} \mathrm{C}_{\text {phytoplankton }}$ as $\delta^{13} \mathrm{C}_{\mathrm{R}}$ estimates. All values were calculated when $\delta^{13} \mathrm{C}_{\text {tissues }}$ was in steady-state with $\delta^{13} \mathrm{C}_{\text {algae }}$ (from 19 July to 16 August 2011). The sample size is given in brackets.

\begin{tabular}{|c|c|c|c|c|c|}
\hline \multirow[t]{2}{*}{ Tissues } & \multicolumn{3}{|c|}{$\delta^{13} \mathrm{C}$ mean \pm S.D. (number of samples) } & \multicolumn{2}{|c|}{$\% \mathrm{C}_{\mathrm{M}}$ mean \pm S.D. (number of samples) } \\
\hline & Treatment T15 & Treatment T21 & Treatment T25 & Treatment T15 & Treatment T21 \\
\hline muscle & $-37.9 \pm 3.4(15)$ & $-37.5 \pm 3.0(15)$ & $-36.2 \pm 2.6(15)$ & $6.0 \pm 1.3(4)$ & $6.8 \pm 2.5(5)$ \\
\hline mantle & $-39.3 \pm 2.8(15)$ & $-39.7 \pm 2.3(15)$ & $-37.3 \pm 2.6(15)$ & $5.9 \pm 1.2(4)$ & $6.4 \pm 2.4(5)$ \\
\hline gills & $-45.0 \pm 1.7(15)$ & $-45.5 \pm 1.5(15)$ & $-39.8 \pm 3.3(15)$ & $5.1 \pm 1.0(4)$ & $5.5 \pm 2.0(5)$ \\
\hline digestive gland & $-52.5 \pm 2.0(15)$ & $-52.1 \pm 1.6(15)$ & $-48.1 \pm 3.8(15)$ & $4.3 \pm 0.9(4)$ & $4.8 \pm 1.8(5)$ \\
\hline phytoplankton & $-54.4 \pm 1.2(5)$ & $-53.8 \pm 1.7(5)$ & $-54.4 \pm 1.2(5)$ & $4.8 \pm 1.1(7)$ & $5.3 \pm 2.1(9)$ \\
\hline
\end{tabular}

